\title{
MOST FREQUENT NEMATODE PARASITES OF ARTIFICIALLY RAISED PHEASANTS (PHASIANUS COLCHICUS L.) AND MEASURES FOR THEIR CONTROL
}

PAVLOVIĆ I*, JAKIĆ-DIMIĆ DOBRILA *, KULIŠIĆ Z ** and FLORESTEAN IULIA***

*Scientific Veterinary Institute of Serbia, Belgrade, **Faculty of Veterinary Medicine, Belgrade, $\star * \star$ Directia Sanitara Veterinara lasi, lasi, Romania

(Received 7. August 2003)

Helminthoses have an important role in the pathology of artificially raised game pheasants. During the period 1997-2002. we examined a total of 1893 pheasant poults aged from 4 to 14 weeks and 1432 adult birds at several pheasanteries in Serbia.

The following nematode species were found: Syngamus trachea, Ascaridia galli, A. columbae, Heterakis gallinarum, H. isolonche, Capillaria gallinae (sin. C. caudinflata), C. columbae (sin. C. obsignata) and C. phasianis.

The intensity of infection in total was not high, except for infection with ascaridata and gapeworms, and depended of age of the examined birds.

Consisting of anthelmintic drugs mixed with meal gave the most favourable results in therapy on rhe medicated food.

Key words: pheasants, Phasianus colchicus, nematodes, therapy

\section{INTRODUCTION}

Parasitoses caused by helminths produce health problems in free-living and artificially raised pheasants. Nematode infestation is the most frequently infection transmited throught intermediate host to the pheasant population. Earlier examination have shown that helminths normally occur in farm bred pheasants and occupyan important place in the pathology of these birds (Bejšovec, 1971; Okulewicz and Modrzejewska, 1980; Kazacos et al., 1986; Chroust, 1990; Schrike, 1991). In Serbia, the prevalence of parasites was earlier examined only by Nevenić (1960), Pavlović (1990a, 1990b, 1991) and Pavlović et al. (1992, 1995, 1996)

During artificial breeding we have the possibility to control helminth infections using various anthelmintic drugs mixed in the feed for pheasants. In this paper we give an outline of the nematode fauna of artificially raised pheasants and measures for its control.

\section{MATERIAL AND METHODS}

The investigation was carried out in 12 pheasanteries in Serbia in the period 1997-2002. using samples of faeces and dead pheasants. Samples of faeces 
were collected monthly from the bird flocks and examined using the sedimentation and flotation concentration technique as described by Euseby (1981). A total 1893 pheasants up to 14 weeks old and 1432 adult pheasants were examined by parasitological necropsy.

The keys given by Soulsby (1977) were used to classify the helminths found.

After diagnosis one of the folloving anthelmintics: mebendazole, fenbendazole, levamizole, cambendazole, pyranteltartarat, thiabendazole, tetramizolchloride or piperazine was at once mixed in the feed.

The therapeutic efficacy of the anthelmintic drugs was examined at necropsy and by coprological examination.

\section{RESULTS AND DISCUSSION}

Infection with helminths we found in $41.83 \%$ (792/1893) of the pheasants up to 14 weeks old and in $33.03 \%(473 / 1432)$ of the adult pheasants. Polyparasitism involving by two species was detected in $341(18.01 \%)$ pheasants up to 14 weeks old and in $343(23.95 \%)$ adult birds.

The following nematode species were found: Syngamus trachea (Montagu, 1811), Ascaridia galli (Schrank, 1788), Ascaridia columbae (Gmelin, 1790), Heterakis gallinarum (Schrank, 1788), Heterakis isolonche (Schrank, 1798), Capillaria gallinae (sin. C. caudinflata) (Kowalewski, 1859), Capillaria columbae (sin. C. obsignata) (Rudolphi, 1819) and Capillaria phasianis (Kotlan, 1940).

In pheasants up to 14 weeks old the most prevalent was Syngamus trachea (37.19\%), followed by Heterakis isolonche (27.97\%), Ascaridia galli (12.98\%), $\mathrm{H}$. gallinarum (11.14\%) and Ascaridia columbae (10.28\%) (Figure 1). Other nematode species were found in less then $10 \%$ of the birds. In these young pheasants group, especially when the infection was of strong intensity, we usually found clinical signs of disease. With intestinal helminths the birds had diarrhea and were markedly emaciated and generally weak. For gapeworm infection the characteristic signs were dyspnoea and asphyxia. The birds shake and toss their heads about and may be caught, or they extend the neck, open the beak and perform gaping movements. With serious infection the mortality reached $15 \%$. Pathological changes were similar to those described by Valenza (1975), Pavlović (1991), Pavlović et al. (1996), Florestean et al. (2001) and Florestean and Pavlović (2003).

Adult pheasants, were infected with the same parasite species but the intensity of infection (except with Syngamus trachea and Ascaridia galli) was not sufficient to induce clinical signs of disease. Syngamus trachea was the most abundance species (34.45\%), followed by Ascaridia galli (23.06\%) and Ascaridia columbae (18.19\%). Heterakis isolonche $(7.41 \%)$ and $\mathrm{H}$. gallinarum $(4.57 \%)$ were less prevalent than in younger birds (Figure 2).

The evident pathological role of those helminthoses in both pheasant populations necessitated decision on the optimal way to treat the infected flocks. After the parasitological examination we mixed suitable antiparasitic drugs in the feed (as a premix) (Cosoaraba and Ciolofan, 1985).

Simple infections with Ascaridia galli or A. columbae were treated most eficcienty with piperazine at $250 \mathrm{mg} / \mathrm{kg}$ at once, and 14 days later again. In cases of 
Acta Veterinaria (Beograd), Vol. 53. No. 5-6, 393-398, 2003.

Pavlović I et al. Most frequent nematode parasites of artificially raised

pheasants (Phasianus colchicus L.) and measures for their control

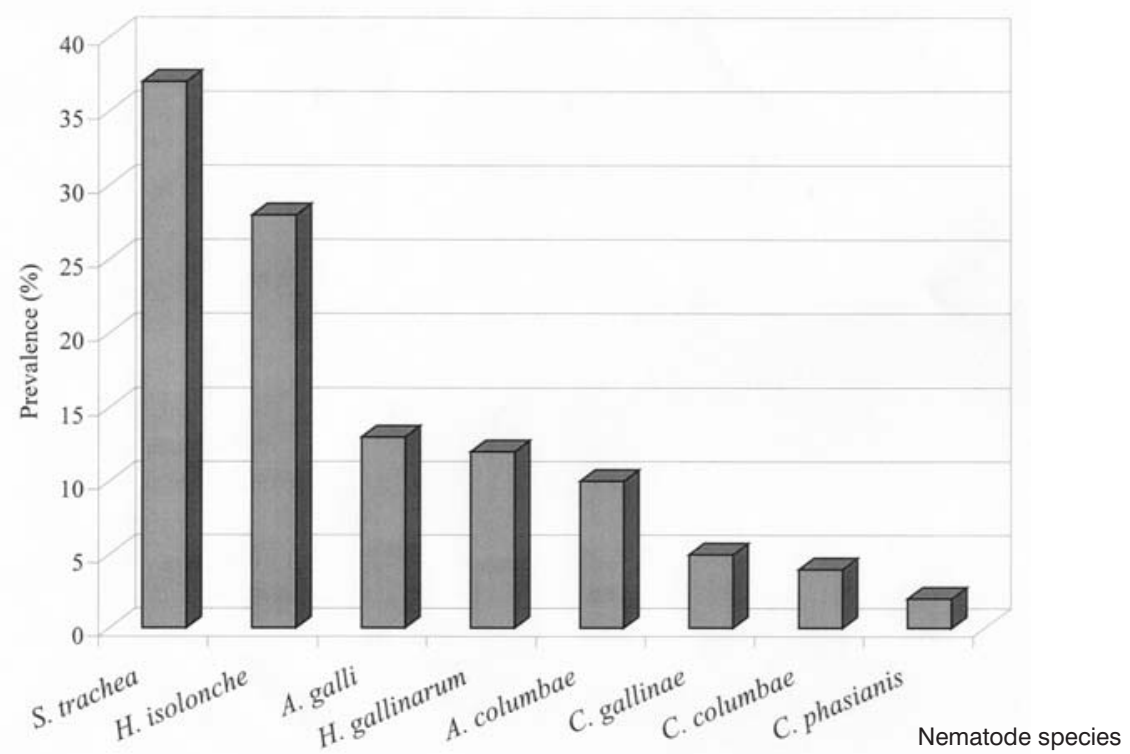

Figure 1. Prevalence of nematode species in pheasants up to 14 weeks old (\%)

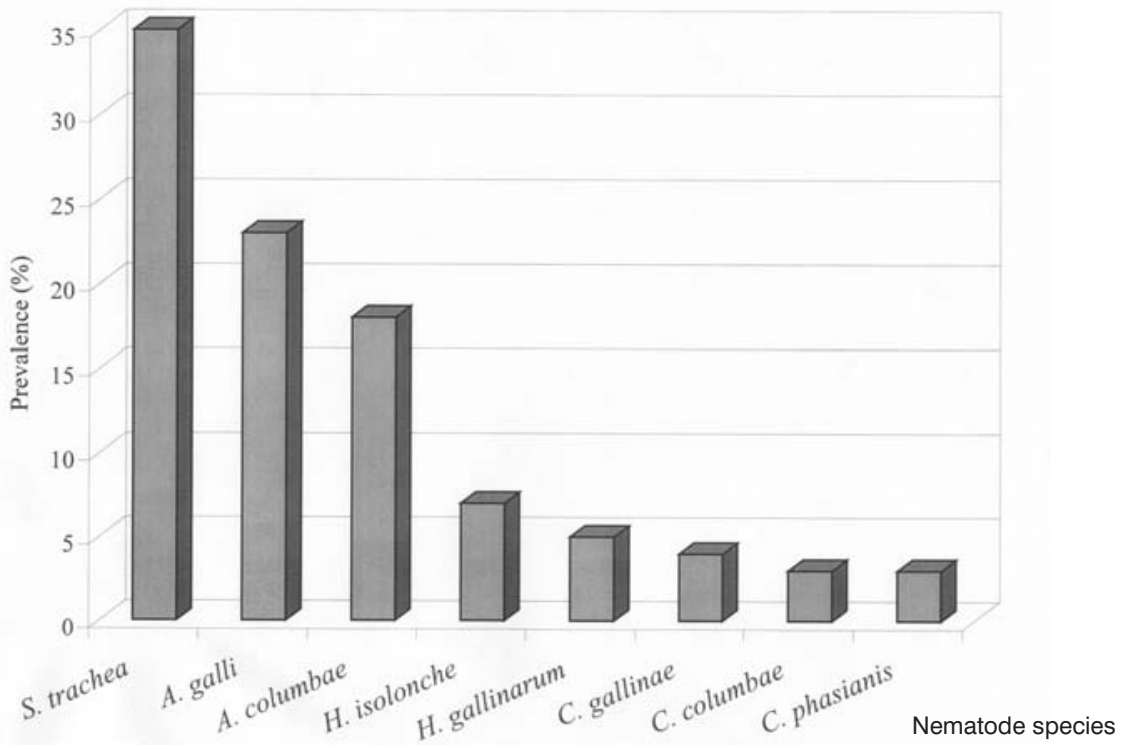

Figure 2. Prevalence of nematode species in adult pheasants (\%) 
mixed infection we used a wide spectrum anthelmintic like mebendazole or fenbendazole. Ascaridosis alone was recorded in $7.71 \%$ of the younger and $8.23 \%$ of the adult birds. The therapeutic effect of piperazine was completely successful. When ascaridosis was present with other nematode helminth species we treated with tetramisole and levamisole at $20-30 \mathrm{mg} / \mathrm{kg}$ of dry food. Mebendanzole was used for 3 successive days in a dosage of $8 \mathrm{mg} / \mathrm{kg}$ of feed. Cambendazole was added at $60 \mathrm{mg} / \mathrm{kg}$ and pyranteltartarat at $100 \mathrm{mg} / \mathrm{kg}$ of feed. All the anthelmintic drugs gave $100 \%$ elimination of parasites.

Gapeworm infection was the most common infection in both populations of pheasants. In both cases the best therapeutic effects were with mebendazole given for 3 days at $30 \mathrm{mg} / \mathrm{kg}$ of feed (100\% efficacy). Fenbendazole administered for 3 days in a dose of $20 \mathrm{mg} / \mathrm{kg}$ or at $100 \mathrm{mg} / \mathrm{kg}$ in a single dose gave full therapeutic efficacy. Favourable results were obtained with tetramizole given for one day in a dosage of $1.5 \mathrm{mg} / \mathrm{kg}$ or at $0.15 \%$ concentration for 6 days. Levamizole in a dosage of $20 \mathrm{mg}$ gave successful results.

Heterakidosis in both population was treated with several anthelmintic drugs. Mebendazole mixed in the feed was successfules used in a therapeutic dosage of $30 \mathrm{mg} / \mathrm{kg}$. Fenbendazole was given for one day at $100 \mathrm{mg} / \mathrm{kg}$ of feed or at $20 \mathrm{mg} / \mathrm{kg}$ for 3 days and had an efficacy of $97 \%$. Thiabendazole $(0.3-1.5 \mathrm{mg} / \mathrm{kg}$ ) and levamizole $(20 \mathrm{mg} / \mathrm{kg}$ ) was very efficient against hetarakis in more than $90 \%$ of cases.

Capillariosis was treated with mebendazole in the feed in a dosage of 30 $\mathrm{mg} / \mathrm{kg}$ for 3 days. Tetramizolechloride at $40 \mathrm{mg} / \mathrm{kg}$ gave a $95 \%$ of reduction of the parasite, while fenbendazole in a dosage of $20 \mathrm{mg} / \mathrm{kg}$ for one day had a $100 \%$ therapeutic effect. Similar results were obtained with levamizole in a dosage of 30 $\mathrm{mg} / \mathrm{kg}$.

Comparing the results obtained with those of other similar examinations (Bickford and Gaffar, 1966; Franck, 1977; Pence et al., 1980; Perilo, 1980; Githokopoulus, 1984a,b), we concluded that the helminth species found, which excluded Ornythostrongylus quadriradiatus, have a worldwide distribution with a similar rate of infection. These nematode species have a wide range of distribution in the bird population and have been found in pigeons, fowls and other free living and breeding bird species (Bejšovec, 1971; Okulewicz and Modrezejawska, 1980). The same parasite species occurred in pigeons in Serbia (Kulišić, 1988, 1989a, 1989b; Kulišić et al., 1996) and in domestic fowls (Pavlović et al., 1997a). Many intermediate hosts (arthropods) and free living breeding birds infected with these helminth species allow transmission to the pheasant populations artificially bred (Bejšovec, 1976; Pavlović et al., 1990c).

Therapy with medicated feed is the only efficient method to control the presence of theses nematode parasites species in farm bred pheasants (Kirsch, 1985; Kulišić et al., 1993; Lamka et al., 1997). This was confirmed here by examination of the infected flocks after treatment.

\section{ACKNOWLEDEMENT}

This study is supported by the Ministry of Science, Technology and Development of the Republic of Serbia (Project No 1556 "Epidemiological characteristics of most important infectious diseases of ani- 
Acta Veterinaria (Beograd), Vol. 53. No. 5-6, 393-398, 2003.

mals and zoonoses" and Project No 4332 "New methods and diagnostic procedure in bacterial and parasitic diseases of domestic animal").

Address for correspondence:

Pavlović I

ScientificVeterinary Institute of Serbia,

Vojvode Toze 14

11000 Belgrade, Serbia \& Montenegro

\section{REFERENCE}

1. Bejšovec J, 1971, The helminths of the chickens and the pheasants on sites of their mutual contact. Helminthologia 11, 1/4, 155-60.

2. Bejšovec J, 1976, Ecology of syngamosis in a large scale farming area. Angew Parasitol., 17, 4 196-207.

3. Bickford AA, Gaafar SU, 1966, Multiple capillariasis in game farm pheasants. Avian Disease, 10, 428-53.

4. Chroust K, 1990, Parazitofauna bažanta obecneho, bažanta kralovskeho a krocana divokeho ve společnych lokalitach. Folia Venitoria, 20, 211-9.

5. Cosoaraba J, Ciolofan I, 1985, Controlul capilaiozei si singamozei in crescatoriile de fazani si potirinichi. Lucrari Stiintifice Medicina Veterinara, 27, 69-73.

6. Euzeby J, 1981, Diagnosis Experimental des Helminthoses Animales. ITSV, Paris.

7. Franck C, 1977, The first report of Heterakis isolonche in the Buckland, Angewend Parasitologie, 18, 3, 162-3.

8. Florestean I, Florestean V, Uraschi G, Costachescu E, 2001, Investigatii clinice si morfopatologice in capillarioza esofago-ingluvinala a fazanilor de crescatorie. Lucrari Stiintifice Medicina Veterinara, 44, 586-9.

9. Florestean I, Pavlović I, 2003, The first occurence of Thominx cyanopicae (Lopez-Neryra,1949) at pheasants (Phasianus colchicus L.). Acta Veterinaria 53, 2-3, 183-90.

10. Githkopoulos PR, 1984a, Capillaria phasianina in pheasants (Phasianus colchicus mongolicus) and partridges (Alectorius chunar). Helleike Kteniatrike, 27, 1, 8-12.

11. Githkopoulos PR, 1984b, Helminths in pheasants of Greek pheasanteries. Hellenike Kteniatrike, 27, 1, 68-76.

12. Kazacos KR, Reed WM, Thacker HL, 1986, Cerebrospinal nematodiasis in pheasants. J Am Vet Med Assoc., 15, 189, 10, 1353-4.

13. Kirsch $R, 1984$, Treatment of nematodiasis in poultry and game birds with fenbendazole. Avian Dis., 28, 2, 311-8.

14. Kulišić Z, 1988, Endoparasite fauna of pigeons (Columba livia) as detected in the city of Belgrade. Acta veterinaria, 38, 1, 37-42.

15. Kulišić Z, 1989a, Parasitical infection among pigeons (Columba livia) of different ages in area of Belgrade. Acta veterinaria, 39, 2-3, 155-62.

16. Kulišić Z, 1989b, Fauna parazita golubova (Columba livia) na području Beograda. Veterinarski glasnik, 43, 10, 847-52.

17. Kulišić Z, Pavlović I, Rosić G, Bajić Vesna, Lazarov Dubravka, 1993, Efekat mebendazola u lečenju pernate lovne divljači i kontrolisano gajenih golubova. Zbornik kratkih sadržaja VI savetovanja veterinara Srbije, Zlatibor, 49.

18. Kulišić Z, Pavlović I, Milutinović Marija, 1996, Prilog poznavanju parazitofaune golubova sa područja Beograda u periodu 1990-1994. godine. Veterinarski glasnik, 50, 9-10, 785-90.

19. Lamka J, Svobodova V, Slezkova J, 1997, Anthelmintic efficacy of ivermectin against Syngamus trachea and Capillaria spp. in pheasant. Vet Med (Praha), 42, 6, 157-60.

20. Nevenić $V$, 1960, Zaštita fazana od bolesti, specijalno invazionih u raznim fazama prirodnog i veštačkog uzgoja. Veterinarski glasnik, 14, 10, 769-74. 
21. Okulewitz A, Modrezejavska M, 1980, Helminth fauna of pheasants (Phasianus colchicus L.) from the environs of Wroclaw in the autumn/winter period. Wiadomedia Parazitologia, 26, 1, 73-5.

22. Pavlović I, Hudina V, Kerš V, Blažin V, Čupić V, 1990a, Helmintološka fauna fazana u Beogradskom zoovrtu u periodu od marta do avgusta 1988. godine. Veterinarski glasnik, 44, 6, 467-71.

23. Pavlović I, 1990b, Parazitofauna fazana na teritoriji grada Beograda. Zbornik radova $i$ kratkih sadržaja radova VI simpozijuma male životinje, urbana sredina i ekologija, Sarajevo, 137-9.

24. Pavlović I, 1991, Ekto i endoparaziti fazana u farmskom odgoju i mere za njihovo suzbijanje. Magistarska teza, Fakultet veterinarske medicine u Beogradu.

25. Pavlović I, Kerš-Pavlović V, Jordanović B, Hudina V, 1992, Endoparasites of pheasants artificialy raised. Lucrari Stiitentifici Medicina Veterinara 26, 104-7.

26. Pavlović I, Kulišić Z, Nešić D, Milutinović M, Valter D, 1995, Helminthoses of free living pheasants (Phasianus colchicus L.) in Serbia, Programe and Abstracts of Seventh Interrnational Helminthological Symposium. Košice, Slovak Republic, 43.

27. Pavlović I, Ivetić V, Kulišić Z, Valter D, Nešić D, 1996, Značaj helminata u zdravstvenoj problematici fazana u veštačkom odgoju. Veterinarski glasnik, 50, 3-4, 209-13.

28. Pence DB, Young VE, Guthery FS, 1980, Helminths of ring-necked Phasianus colchicus (Gmelin), (Phasianidae) from Texas panhendle. Proceeding of Helminthology, 41, 45-7.

29. Soulsby EJL, 1977, Helminths, Arthropods and Protozoa of Domesticated Animals. Bailliere, Tindall and Cassell ed., London.

30. Valenza F, 1975, Pathological anatomy and tracheal granuloma due to Syngamus trachea in the pheasant. Folia Vet Lat., 5, 2, 339-46.

\title{
NEMATODE PARAZITI FAZANA (PHASIANUS COLCHICUS L.) U KONTROLISANOM DRŽANJU I MERE KONTROLE
}

\author{
PAVLOVIĆ I, JAKIĆ-DIMIĆ DOBRILA, KULIŠIĆ Z i FLORESTEAN IULIA
}

\section{SADRŽAJ}

Sistematskim parazitološkim istraživanjima fazana u veštačkom odgoju, sprovednim na 12 fazanerija u Srbiji u periodu od 1987-2002. godine ustanovljeno je 14 vrsta helminata.

Kod fazanskih pilića do 4 nedelje starosti nisu ustanovljene infekcije. Kod fazana u starosti od 4 do 14 nedelja infekcija je ustnovljena kod 41,83\% ptica a kod odraslih fazana u 33,03\%. Poliparazitizam je ustanovljen kod 18,01\% fazana do 14 nedelja starosti i kod 23,95\% odraslih fazana. Najšire prisutna infekcija u obe populacije je bila uzrokovana sa Syngamus trachea.

Suzbijanje endoparazita fazana u kontrolisanom odgoju sprovedeno je putem davanja antihelmintika (mebendazol, fenbendazol, levamizol, kambendazol, pirantel tartarat, tabendazol, tetramizol hlorid i piperazin) kroz hranu čime se postiže optimalni antinematodni učinak. 